\title{
Mother-friendly hospital programme of Turkey: national intervention to improve the quality of maternity services
}

Nüket Erbaydar ${ }^{1}$

${ }^{1}$ Department of Public Health, Faculty of Medicine, Hacettepe University, Ankara, Turkey. (Correspondence to: Nüket Erbaydar: erbaydar@hacettepe. edu.tr).

\begin{abstract}
Background: The mother-friendly care model and mother-friendly programmes are powerful responses to solve problems in maternity care services including high rates of caesarean section, low breastfeeding rates, and women's rights issues.
\end{abstract}

Aims: This paper describes the development and implementation of the mother-friendly hospital programme of Turkey.

Methods: The Ministry of Health initiated the mother-friendly hospital programme in 2010. National mother-friendly hospital standards, guidelines and evaluation tools were developed. Implementation began in 2015.

Results: Training activities were carried out to enable health care workers (e.g. physicians, midwives, nurses) to train staff of hospitals applying to the programme, and to evaluate and monitor their maternity services; 455 health care workers were trained. Participation in the programme is voluntary and hospitals apply for certification. To apply, the hospital's caesarean section rate must be lower than the country average. As of January 2020, 73 hospitals have been certified as mother-friendly hospitals.

Conclusion: As a practical implementation of the mother-friendly approach, Turkey's experience may be useful to other health systems.

Keywords: mother-friendly hospital, maternal health services, reproductive health, Turkey

Citation: Erbaydar N. Mother-friendly hospital programme of Turkey: national intervention to improve the quality of maternity services. East Mediterr Health J. 2021;27(2):202-210. https://doi.org/10.26719/emhj.20.138

Received: 15/05/19; accepted: 12/02/20

Copyright (C) World Health Organization (WHO) 2021. Open Access. Some rights reserved. This work is available under the CC BY-NC-SA 3.o IGO license (https://creativecommons.org/licenses/by-nc-sa/3.o/igo)

\section{Introduction}

The mother-friendly programme of Turkey was initiated in 2010 and the pilot implementation in 2015. The concept of mother-friendly, which first appeared in the 1990s, is a new way of emphasizing the quality of childbirth services in the health system. In the current understanding, the mother-friendly concept concerns the rights approach as a response to the abuse (e.g. physical, verbal, violation of privacy) and neglect in maternity services, the lack of quality care and the use of the non-evidence-based interventions, particularly in developing regions (1).

The core philosophy of the mother-friendly concept is centred on the woman and her baby during pregnancy, childbirth and the postnatal period. The concept comprises some medical ethics principles such as "Do no harm" and "Responsibility" which have also substantial legal grounds based on international regulations (1). According to the mother-friendly concept, birth is a normal and natural biological process. Women and babies have inherent wisdom, which is necessary for childbirth, and breastfeeding provides the optimum nourishment for newborns and infants. The midwifery model of care is the most appropriate for most women during pregnancy and birth (2).

The first organization launched in 1996 to develop the principles and guidelines for mother-friendly care was the Coalition for Improving Maternity Services in the United State of America (3). In 2003, the World Health Organization (WHO) adopted the mother-friendly concept (4). International organizations such as WHO, White Ribbon Alliance and the International MotherBaby Childbirth Initiative have developed statements to ensure the dignity and the rights of childbearing women $(3,5,6)$. In 2015, a working group formed by these organizations and in collaboration with the International Paediatric Association and International Confederation of Midwives developed criteria for certification of a facility as mother and baby-friendly (1) Theses criteria are based on the principles of the mother-friendly philosophy and focusing on labour, delivery and peripartum practices.

Also in 2015, WHO developed its strategies for ending preventable maternal mortality in accordance with Sustainable Development Goal 3 (Ensure healthy lives and promote well-being for all at all ages), in particular SDG 3.1: by 2030 , reduce the global maternal mortality ratio to less than 70 per 100 ooo live births. The empowerment of women and girls, protection and support of mother and baby, and ensuring high-quality reproductive, maternal and newborn health care for all who need it are the goals of ending preventable maternal mortality (7).

Mother-friendly programmes may act as powerful incentives for countries, including Turkey, which face problems such as low-quality maternity care services, 
high rates of caesarean section and low rates of breastfeeding.

This paper aims to describe the development and implementation processes of the mother-friendly hospital programme in Turkey.

\section{Maternity health services in Turkey}

Maternal health services are stipulated in the Constitution of Turkey and the Ministry of Health of Turkey provides these services at primary, secondary and tertiary levels. Maternal care is one of the main duties of family physicians working in family medicine units, of which there were 21696 in 2015. Secondary level maternal health services are provided in general hospitals, which should have at least one specialist in obstetrics and gynaecology. Turkey had 1406 such hospitals in 2015. The third level of maternal health services includes maternity and child hospitals (there were 36 in 2015) and university hospitals (there were 70 in 2015) (8). In 2015, antenatal care coverage (at least one visit during pregnancy) was 98\% and $99 \%$ of births took place in hospital (8). The number of live births in Turkey in 2015 was 1325783 and the total fertility rate was about 2.14 (9). Turkey was also listed as one of the countries that had achieved the Millennium Development Goal (MDG) on maternal mortality - the maternal mortality ratio decreased from 103.3 to 15.8 per 100000 live births between 1990 and 2015 (10).

Despite all these developments, some important maternal health problems remain in Turkey. Women are increasingly attended by an obstetrician when giving birth and the proportion of midwife-attended deliveries has been decreasing. Only $18.7 \%$ of deliveries were attended by a midwife in 2013 (11). Non-evidence-based obstetric practices are common in the country, including the administration of routine enemas, restriction of mobility and nutrition, routine procedures to speed up labour, supine position for delivery, routine episiotomy, and lack of active management in the third stage of labour. Women are not allowed to have a companion (a partner or relative) present during labour. In addition, pregnant women do not have enough knowledge and skills about pregnancy and childbirth, which is essential to make informed choices. There are also communication problems between pregnant women and the staff of maternity units (12)

An important problem in maternal health is the substantial increase in the proportion of caesarean sections in Turkey. The caesarean section rate was $14.3 \%$ in 1993 and had increased to $51.9 \%$ by 2013 (13). Turkey has one of the highest rates of caesarean section globally - in 2015 the caesarean section rate was $53.1 \%$ and the primary (first) caesarean section rate was $27.2 \%$ ) (8) - and has the highest caesarean section rate in countries of the Organisation for Economic Co-operation and Development (OECD) (14). In the WHO Eastern Mediterranean Region, several countries have similar rates of caesarean section, such as Egypt (51.8\% in 2009-
2014), Lebanon (47.1\% in 2016), and the Islamic Republic of Iran (45.6\% in 2014) (15).

Other continuing maternal and child health problems of Turkey include low levels of early initiation of breastfeeding (within 1 hour if delivery) and exclusive breastfeeding for less than 6 months. As found in the 2013 Demographic and Health Survey for Turkey, only 50.5\% of babies born in hospitals were breastfed within 1 hour of birth and the rate of exclusive breastfeeding at 4-5 months was only $9.5 \%$ for all babies (11).

While improvements in maternal health care in the country have taken place through new strategic plans and regulations $(16,17)$, a review of maternal health services is nonetheless needed to respond to the above-mentioned persistent problems.

\section{Mother-friendly hospital programme of Turkey}

In response to the existing maternal and child health care problems, the mother-friendly hospital programme was launched as a national programme in Turkey. The basis of this programme is to redefine the policy of the Ministry of Health on pregnancy and childbirth according to women's rights and the reproductive rights of women, and to reorganize the maternity services implemented throughout the country. The primary objective is to ensure that mothers are able to access safe and good-quality delivery services by increasing the quality and quantity of maternal health services. The programme also aims to encourage normal births and reduce intervention rates.

The rules and guidelines on implementing the programme by local health authorities throughout the country have been published. These documents can be accessed from the relevant web page of the Ministry of Health, circular 2018/27 and its annexes (18).

The mother-friendly hospital programme enables woman to access full antenatal care and childbirth services, using an approach that supports women. According to this programme, health providers should intervene only if medical problems arise. Women who have previously delivered by caesarean section also benefit from the maternity services in mother-friendly hospitals. By improving the quality of services and strengthening evidence-based approaches, women who have had previous caesarean sections have a better chance of having a vaginal birth at mother-friendly hospitals.

\section{Development steps}

Activities of the mother-friendly hospital programme began in 2010, and consisted of three phases.

\section{Preparation phase (2010-2015)}

The establishment of a scientific committee within the Department of Women and Reproductive Health of the General Directorate of Public Health of the Ministry of Health was the first step for the programme. As well as the technical staff of the Ministry of Health, academics 
in obstetrics and gynaecology, midwifery, nursing and public health were included in the committee. While developing the national criteria, the scientific committee took into account international developments and recommendations of WHO and revised the programme according to new progress (6,19-22).

Turkey developed its own national criteria according to the principles of the national mother-friendly hospital programme. These criteria are given in Table 1. After developing the criteria, the Department of Women and Reproductive Health worked with a scientific consultant and a technical team to implement these criteria within a programme and develop national guidelines.

\section{Pilot phase (2015-2018)}

The administrative body of hospitals in the country collaborated under the management of the Ministry of Health and the pilot programme began in 2015 with three volunteer hospitals in a western province of Turkey. The training and evaluation of these hospitals were conducted by a technical team and consultant. Based on the experiences in these hospitals, the evaluation process of the programme was improved.

A dissemination meeting was organized to familiarize the health directors of the provinces with the programme and to encourage them to prepare the hospitals of their province to apply the programme. The directors and birthing unit teams of the first three volunteer hospitals also shared their experiences as a mother-friendly hospital.

The Ministry of Health provides cash incentives to the public hospitals to reward those that have been certified as a mother-friendly hospital.

After resource allocation for training of trainers and evaluators who will take part in the programme, courses were started in 2015. Participants were physicians (obstetricians and gynaecologists, public health specialists, and general practitioners), midwives, nurses, and members of the service quality standards' unit of the Ministry of Health. The trainers of trainers and evaluators consisted of the technical team, consultants and academics. The main purpose of the courses was to enable the participants to train the staff of hospitals that were candidates for becoming a mother-friendly hospitals, and to provide them with the knowledge and skills necessary to evaluate and monitor the maternity services of hospitals in accordance with the programme criteria. The courses ran for 5 days and 14 groups were trained which resulted in 455 health care workers throughout the country being certified as mother-friendly hospital trainers and evaluators. (The pilot hospitals were certificated by the programme directors and consultant). The first hospital visit of the trainers and evaluators was conducted with the participation of the trainer of trainers and senior evaluators to support their practice.

\section{Implementation phase (2018 to date)}

The Ministry of Health issued a circular in October 2018 which provided the final structure of the programme.
With the circular, provincial health directorates could manage the training and evaluation processes of the mother-friendly hospital programme in their respective provinces. The first step for the candidate hospital is to apply to the provincial health directorate of the Ministry of Health to start the process (Figure 1). Trainers from the province visit the hospital several times and work with the administrative body and maternity unit staff to prepare the hospital for the final evaluation. The preparation phase of the hospital lasts about a year including the training of staff. The training programme for the hospital staff is scheduled by the trainers and administrative body of the hospital. In large hospitals, this training can be conducted in several sessions. The hospital's administrative body and staff of the maternity unit, maternity services and newborn services should participate in the training programme and schedule an in-service training programme on a yearly basis.

The participation of hospitals in the programme is voluntary. Some preconditions are defined for a hospital to participate in the mother-friendly hospital programme. The most important condition is that the primary caesarean section rate of the hospital should be lower than the average rate of the country - it was $26.3 \%$ in 2018 (23).

As of January 2020, 73 hospitals have been certified as mother-friendly hospitals. Two of these hospitals were university hospitals, two were private-sector hospitals, four of which were third-level hospitals for women, childbirth and children, and others were public hospitals. Re-evaluation of the certified hospitals is done every year. The hospitals that joined the programme in the earliest phase have had four re-evaluations so far. In 2020, the trainer and evaluator teams will complete the first training and evaluations of the new candidate hospitals and 73 re-evaluation visits.

The mother-friendly hospital programme was included in the draft of Strategic Plan of the Ministry of Health 2019-2023 with the aim of increasing the number of mother-friendly hospitals to 200 by 2023 .

The outcome indicators of the programme include an increase in: the proportion of hospitals achieving the objective evaluation scores of the programme; and the proportion of childbirths at hospitals attended by midwives. The compulsory requirements of the programme are labour in single rooms, labour with the attendance of a partner or relative, freedom to move during first and second stages of labour, and early skin-toskin contact between mother and baby. The programme aims to eliminate non-evidence-based interventions in pregnant women who give birth in maternity units such as: withholding food or water, giving enemas, shaving, inducing labour with oxytocin, applying fundal pressure (Kristeller manoeuvre) and performing an episiotomy. The data on these indicators are gathered through reevaluation visits and provincial reports transferred regularly to the Directorate of Women and Reproductive Health. All certified mother-friendly hospitals have 
1. Access to safe and good-quality pregnancy follow-up and delivery services is the right of all pregnant women

2. Counselling services should be provided during pregnancy, delivery and the postnatal period

3. In hospitals, ambulatory services, training, counselling and childbirth, services should comply with the standards in Ministry of Health regulations.

4. Privacy requirements must be met with care; hygiene and comfort standards should be kept high.

5. Non-evidence-based interventions should not be routinely used.
- The services to be provided during pregnancy, delivery and the postpartum period should be presented in such a way that this right is considered.

Pregnant women should have pregnancy classes before delivery.

- Information materials (e.g. written, visual and models) for pregnancy, childbirth and postpartum period should be available for pregnant women and their relatives.

- Pregnant women and their relatives should be informed about the positive and negative consequences of childbirth and the interventions that they may meet in this process.

- Follow-up during the antenatal and puerperal periods should be done in accordance with written follow-up protocols based on current scientific evidence.

- Hospitals should have maternity care units that can provide continuous services, which are arranged according to the needs of mothers and babies.

- Institutions should be responsible for the quality of care they provide.

- It should be ensured that the personnel who work in the delivery units of hospitals have one-to-one contact with each pregnant woman and communicate well with them.

- Institutions with inpatient care should take the necessary measures to ensure safe blood transfusion services and prevent hospital infections.

- Pregnant women should feel comfortable and be free to choose a relative to accompany them.

- During delivery, physical and emotional support should be provided and pregnant women should be able to reach this support with ease.

- There should be no position restrictions for pregnant women; they should be able to walk and move freely. The supine position for pregnant women should be avoided and they should be encouraged to push out their baby in a vertical position.

- Pregnant women should not have fasted; fluid intake should not be stopped at any time during the delivery

- Interventions such as enemas or shaving should not be routinely done.

- Induction of labour should not be performed routinely, early amniotomy should not be done.

- A urethral catheter should not be applied routinely.

- The use of non-medication methods to cope with childbirth pain should be supported.

- The institution's caesarean rate should be within acceptable limits.

6. Human resources and logistical support required - The necessary equipment and consumables should be at the optimal level, and supply for service delivery should be at an optimum level

7. In emergency obstetric conditions, referral criteria should be followed.

- In emergency obstetric cases, the necessary medical intervention should be done immediately.

- The patient should be transferred from one hospital to another after stabilization.

- The hospital staff who is responsible for referral should contact the medical emergency call number. (112).

- Information about cases should be obtained from the referral institution and all information should be recorded.

8. The delivery services should be mother- and baby-oriented.

- The criteria of a baby-friendly hospital must be applied.

- The mother, father and other family members should be encouraged to hold the baby and be able to touch them.

- The mother and baby should be kept in the hospital during the puerperal period, at least 24 hours after normal delivery and at least 48 hours after the caesarean section.

9. Training should be planned and implemented in order to increase the knowledge and skill of service providers.

- The continuity of in-service training should be ensured.

- All staff should be informed about the criteria of the mother-friendly hospital and that they should adopt these criteria.

- Mother-friendly hospital health workers should be encouraged to conduct scientific studies and to participate in scientific meetings to improve their professional and scientific capacities.

10. Records of the services given should be kept, ana- - Accurate electronic records on the quality and quantity of the services should be kept lysed regularly and used to improve the services. regularly.

- Written and visual materials, data and information about childbirth services should be available on the website of hospitals and should be accessible to the public. 


\section{Figure 1 Steps of certification for the mother-friendly hospitals in Turkey}

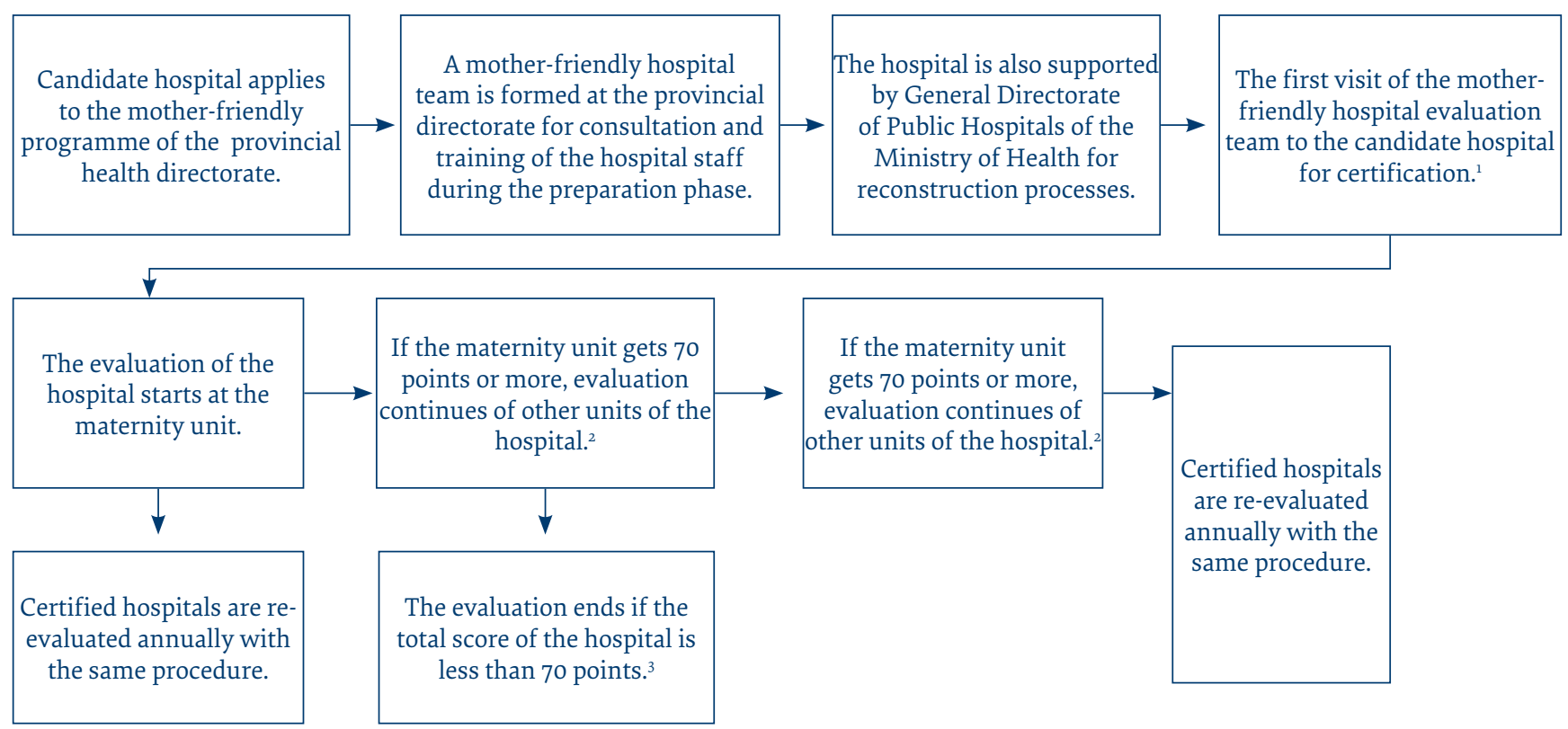

${ }^{1}$ This team consists of five trained staff of the MoHT assigned from another province for objective evaluation and includes at least one OBGYN, one midwife, one service quality evaluator, and one nurse. ${ }^{2}$ Health personnel and mothers are interviewed through questionnaires; hospital units are evaluated through a structured observation form. ${ }^{3} \mathrm{~A}$ detailed report is prepared for the hospital administration. The earliest re-evaluation can be done at least six months later.

maintained their certification as they continue to meet the requirements of the programme.

\section{Discussion}

Turkey's mother-friendly hospital programme responds to the need to revise the maternity health services. Similar efforts exist in other countries. In 2002, Iran Ministry of Health launched the normal physiologic childbirth programme which set out the content of mother-friendly hospital services for the country (24). The mother-friendly childbirth model was also assessed in Taiwan (25), and research was conducted to assess whether maternity services were mother-friendly for early breastfeeding in Lebanon (26). In Egypt, research evaluated whether mother-friendly services could support baby-friendly health services (27).

After the launch of the mother-friendly hospital programme, some studies on the subject have been published in Turkey. One of the earliest studies on mother-friendly hospitals in 2012 found that most of the obstetricians and gynaecologists in Istanbul did not know about the mother-friendly hospital programme in Turkey (28). However, those who knew the programme said that they supported it. The study participants also criticized the conditions in delivery units in Istanbul hospitals where non-evidence-based maternity services were delivered. A preliminary review article in 2014 concluded that by aiming to ensure that birth is a normal, healthy and reliable process, it would be possible to give the necessary confidence and support to mothers (29). Two additional reviews concluded that with the increase in the number of mother-friendly hospitals in the country, more pregnant women may receive birth training, interventions that are not evidence-based will decrease and women's satisfaction with the birth process will increase in more favourable environments and conditions. With the increase in maternal-friendly hospitals, it is hoped that women will be encouraged to have a normal birth and that normal birth rates will also increase (30). A study conducted in a motherfriendly hospital in Ankara examined birth traumas before and after certification and found that the incidence of life-threatening intracranial haemorrhage and hospitalization rates in newborns both decreased (31). The authors recommended that all hospitals in the country provide maternal care based on mother-friendly standards. Another study suggested that more motherfriendly hospitals and pregnancy information classes could help dispel myths about the pregnancy period and childbirth among pregnant women in Turkey (32). Furthermore, satisfaction levels of the mothers who gave birth in mother-friendly hospitals were high, and the satisfaction of the working midwives also increased (33).

Although the number of mother-friendly hospitals has increased in Turkey, the programme is in its initial years and only $10 \%(73 / 730)$ of hospitals have received certification up to January 2020. The effect of the programme at the national level is still unclear. At the institutional level, hospitals should have a primary caesarean section rate lower than the average rate of the country $(26.3 \%$ in 2018$)$ to be a candidate hospital (23). This requirement encourages hospitals to decrease their caesarean section rates before application. Therefore, it is expected that the caesarean section rate in the country will decrease with the increase in certified hospitals. Meanwhile, some important clinical changes, such as a decrease in non-evidence-based interventions in certified hospitals, have been observed (personal observation). However, it is well-known that the increase in caesarean 
Table 2 Factors facilitating and hindering the establishment of the mother-friendly hospital programme of Turkey, by phase of the programme

\begin{tabular}{|c|c|c|}
\hline Preparation phase & Pilot phase & Implementation phase \\
\hline \multicolumn{3}{|c|}{ Facilitating factors } \\
\hline $\begin{array}{l}\text { - Consensus about a need to increase service } \\
\text { quality in maternity units at the Ministry of } \\
\text { Health level } \\
\text { - Political commitment to prevent increases } \\
\text { in caesarean sections } \\
\text { - The capacity of technical staff of the Minis- } \\
\text { try of Health } \\
\text { - Stability of the team in the Department of } \\
\text { Women and Reproductive Health of the } \\
\text { Ministry of Health } \\
\text { - Establishment of a multidisciplinary scien- } \\
\text { tific committee to develop national criteria } \\
\text { for a mother-friendly hospital } \\
\text { - Resource allocation to develop the guide- } \\
\text { lines } \\
\text { Employment of a scientific consultant to } \\
\text { develop the technical infrastructure of the } \\
\text { programme }\end{array}$ & $\begin{array}{l}\text { - Cooperation with three hospitals will- } \\
\text { ing to participate in the programme as } \\
\text { pilot hospitals } \\
\text { - Evaluation of pilot hospitals by the } \\
\text { Ministry of Health core team to put the } \\
\text { forms and guidelines in place } \\
\text { - Ability to organize comprehensive dis- } \\
\text { semination meetings and to encourage } \\
\text { provinces to apply to the programme } \\
\text { Resource allocation by the Ministry of } \\
\text { Health to provide incentives to certifi- } \\
\text { cated hospitals } \\
\text { Resource allocation to carry out train- } \\
\text { ing of trainers and evaluators }\end{array}$ & $\begin{array}{l}\text { - Continued political commitment at the Ministry } \\
\text { of Health level } \\
\text { - Positive recognition of the programme by health } \\
\text { professionals } \\
\text { - Scientific publications supporting the programme } \\
\text { - Positive feedback from the certified hospitals } \\
\text { - Dissemination of the knowledge and positive } \\
\text { experiences of trainers and evaluators } \\
\text { - A comprehensive collaboration with the ba- } \\
\text { by-friendly hospital initiative of Turkey to sup- } \\
\text { port all women who have vaginal or caesarean } \\
\text { delivery in mother-friendly hospitals }\end{array}$ \\
\hline \multicolumn{3}{|c|}{ Hindering factors } \\
\hline $\begin{array}{l}\text { - No well-known international example of } \\
\text { mother-friendly hospital programme at } \\
\text { country level } \\
\text { - Limited knowledge of the mother-friendly } \\
\text { concept of technical staff in the Ministry } \\
\text { of Health. } \\
\text { - Traditionally accepted provider-centred ap- } \\
\text { proach in maternity services } \\
\text { - Difficulties in convincing obstetricians and } \\
\text { gynaecologists about the benefits of the } \\
\text { programme and the criteria } \\
\text { - Routine implementation of non-ev- } \\
\text { idence-based interventions in maternity } \\
\text { units } \\
\text { Common perception that women prefer } \\
\text { caesarean sections }\end{array}$ & $\begin{array}{l}\text { Difficulties in disseminating informa- } \\
\text { tion about mother-friendly health ser- } \\
\text { vices to the provinces due to technical } \\
\text { problems and financing shortages. } \\
\text { - Difficulties in convincing hospital ad- } \\
\text { ministrators to adopt the programme } \\
\text { - Difficulties in finding hospitals willing } \\
\text { to be a candidate for the programme } \\
\text { due to, for example, structural and per- } \\
\text { sonnel shortages in hospitals. } \\
\text { Lack of trainers and evaluators at the } \\
\text { provincial level and difficulties in sup- } \\
\text { porting the candidate hospitals from } \\
\text { the central of Ministry of Health due to } \\
\text { high personnel turnover and shortages } \\
\text { in the central programme team. }\end{array}$ & $\begin{array}{l}\text { Difficulties in maintaining standards of the pro- } \\
\text { gramme due to the increasing number of trainers } \\
\text { and evaluators } \\
\text { - Difficulties in carrying out evaluations and } \\
\text { re-evaluations due to the increasing number of } \\
\text { hospitals in the programme } \\
\text { - High personnel turnover at the Ministry of } \\
\text { Health, and in the provinces and hospitals } \\
\text { - Shortages of obstetricians, gynaecologists and } \\
\text { midwives in hospitals } \\
\text { - Infrastructure problems particularly in old and } \\
\text { large hospitals } \\
\text { - Limited participation of university and private } \\
\text { hospitals } \\
\text { Weak links between primary health care and } \\
\text { hospitals }\end{array}$ \\
\hline
\end{tabular}

sections is a complex phenomenon and it took decades to reach the present rate in the country. Therefore, comprehensive and long-term interventions are needed to reduce that rate to an acceptable level.

Various factors that facilitated and hindered the establishment of the mother-friendly hospital programme in Turkey are summarized in Table 2. The main facilitating factor was the consensus on the need to improve the quality of services in maternity units and the political commitment from the Ministry of Health. As regards barriers to the programme, making a hospital mother-friendly requires a great deal of effort on the part of the hospital, and reconstruction of large and old maternity units is particularly difficult. Therefore, the Ministry of Health started the programme mainly in small and newly constructed hospitals to ensure compatibility with the criteria of the mother-friendly hospital. Personnel shortages in the maternity units of hospitals also prevent them from being candidates. This is particularly true for large tertiary-level hospitals that were the main service providers for childbirth. In addition, the high turnover of staff leads to fewer trained staff in hospitals and directorates, and in the trainer and evaluator group. Discouraging health staff in some maternity units from continuing with their usual and non-evidence-based practices can be difficult. Some obstetricians and gynaecologists still consider caesarean section as a safe alternative to vaginal delivery mainly because of fear of malpractice associated with vaginal delivery (34). The limited participation of university hospitals and private hospitals is another barrier. Those types of hospitals have very high caesarean section rates, and their participation in the programme should be encouraged.

Although Turkey's mother-friendly hospital programme is new, some lessons have been learnt.

- The programme integrates various concepts such as quality of health services, evidence-based maternity care, reproductive rights, women's rights and baby-friendly practices. The spectrum of these integrated concepts provides an easily understandable 
framework for decision-makers as an applicable strategy for clinicians and hospital administrators, and a convincing approach for women's participation.

- High rates of caesarean section are a public health problem for many countries. The experience of the mother-friendly hospital programme in Turkey shows that the holistic approach of the programme has can gain acceptance from different stakeholders and communities. Thus, it can be a useful strategy for decreasing caesarean section rates.

- Obstetricians, gynaecologists and midwives should be empowered. They are the most important partners of the programme, and support them is crucial for the programme's success.

- Additional training sessions for trainers of trainers should be conducted to form the core training team and an optimum number of trainers and evaluators should be retained through regular training sessions.

- Country-level performance reports should be prepared on the improvements in the output indicators of the programme, the budget and challenges.
- Many revisions have been made on the participants' guideline, trainers' guideline and evaluation guideline of the programme to ensure they are practical and functional. All these materials are accessible and ready for evaluation, translation and adaptation for other health systems.

This paper presents the development and implementation process of the mother-friendly hospital program of Turkey and the preliminary experiences. However, evaluations of the process and data on outcome indicators are being gathered only at the hospital level. The availability of country-level data will allow the evaluation of the programme's progress and its effect on maternal health. Research on the programme at all levels is needed. The financial aspect of the programme also requires evaluation.

The mother-friendly hospital programme in Turkey is still in its early phase. Its future success depends on various factors such as technical and financial factors as well as political commitment, which is the most important.

\section{Acknowledgement}

The author thanks Hacettepe University Teknokent Technology Transfer Center for English editing service.

Funding: None.

Competing interests: None declared.

\section{Programme des hôpitaux amis des mères en Turquie : intervention nationale pour améliorer la qualité des services liés à la maternité}

\section{Résumé}

Contexte: Le modèle de soins «amis des mères » est une approche utile permettant de résoudre les problèmes rencontrés dans les services de soins de maternité, y compris les taux élevés de césarienne et les questions relatives aux droits des femmes.

Objectifs : Le présent article décrit l'élaboration et la mise en œuvre du programme des hôpitaux amis des mères en Turquie.

Méthodes : Le ministère de la Santé a lancé le programme des hôpitaux amis des mères en 2010. Des normes, lignes directrices et outils d'évaluation nationaux pour les hôpitaux amis des mères ont été mis au point. La mise en œuvre a débuté en 2015.

Résultats : Des activités de formation ont été menées à bien pour permettre aux agents de santé (médecins, sagesfemmes, personnels infirmiers) de former le personnel des hôpitaux candidats au programme, d'évaluer et de suivre leurs services de maternité ; 455 agents de santé ont été formés. La participation au programme est volontaire et les hôpitaux présentent une demande de certification. Pour poser sa candidature, l'hôpital doit avoir un taux de césarienne inférieur à la moyenne du pays. En date de janvier 2020, 73 hôpitaux ont été certifiés « hôpitaux amis des mères ».

Conclusion : Dans la mise en œuvre pratique de l'approche des hôpitaux amis des mères, l'expérience turque pourrait être utile à d'autres systèmes de santé. 


\section{برنامج المستشفيات الملائمة للأمهات في تركيا: تدخل وطني لتحسين نوعية خدمات الأمومة \\ نوكيت أربيدار}

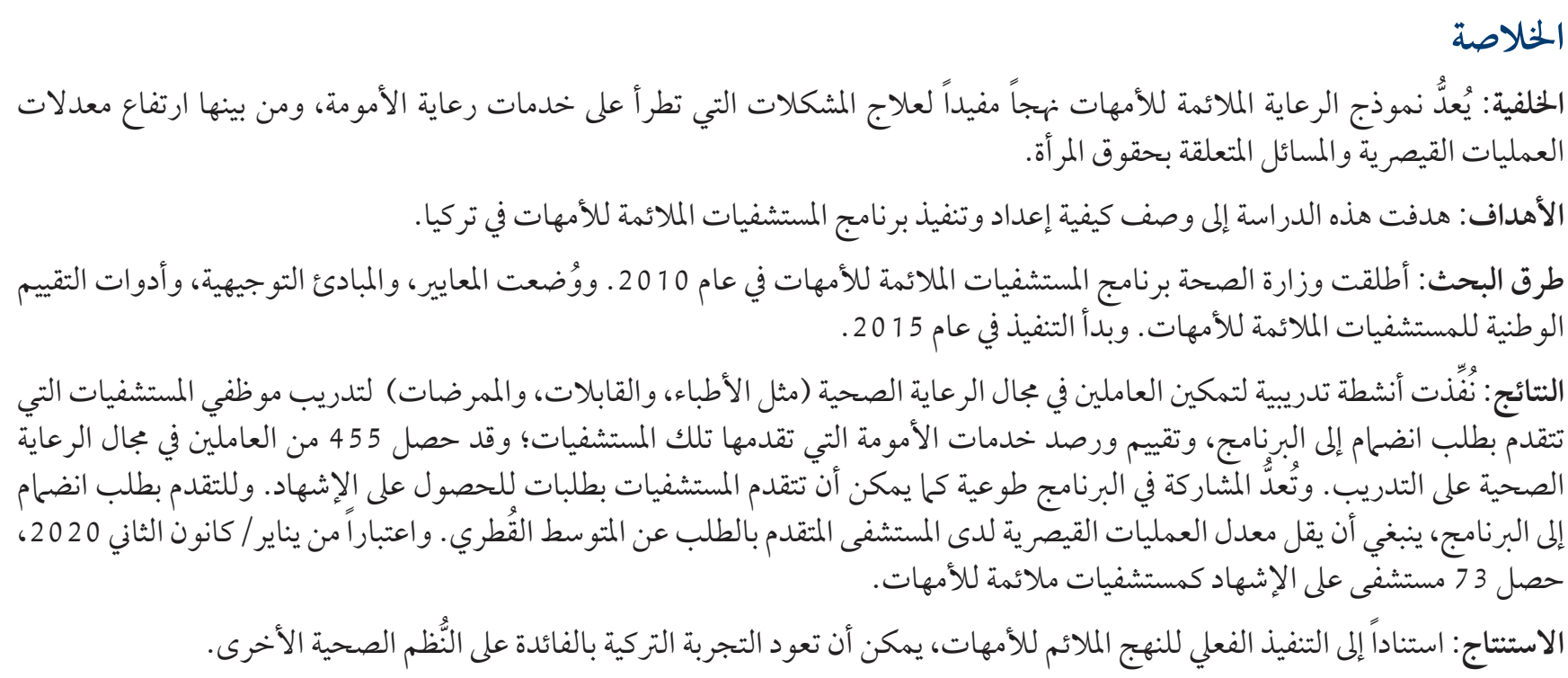

\section{References}

1. International Federation of Gynecology and Obstetrics, International Confederation of Midwives, White Ribbon Alliance, International Pediatric Association, World Health Organization. Mother-baby friendly birthing facilities. Int J Gynaecol Obstet. 2015;128(2):95-9. http://doi.org/10.1016/j.ijgo.2014.10.013

2. Hotelling BA. The coalition for improving maternity services: evidence basis for the ten steps of mother-friendly care. J Perinat Educ. 2007;16(2):38-43. https://doi.org/10.1624/105812407X197744

3. Davis-Floyd R, Pascali-Bonaro D, Leslie MS, Ponce de León RG, Rodolfo G. The International Mother Baby Childbirth Initiative: working to create optimal maternity care worldwide. Int J Childbirth. 2011;1(3):196-212. http://doi.org/10.1891/2156-5287.1.3.196

4. World Health Organization \& LINKAGES. Infant and young child feeding: a tool for assessing national practices, policies and programmes. Geneva: World Health Organization; 2003 (https://apps.who.int/iris/handle/10665/42794, accessed 18 October 2019).

5. The prevention and elimination of disrespect and abuse during facility-based childbirth: WHO statement. Geneva: World Health Organization; 2014 (http://apps.who.int/iris/bitstream/10665/134588/1/WHO_RHR_14.23_eng.pdf?ua=1\&ua=1, accessed 9 August 2019).

6. Respectful maternity care: the universal rights of child-bearing women. Washington (DC): White Ribbon Alliance; 2011 (https:// www.whiteribbonalliance.org/wp-content/uploads/2017/11/Final_RMC_Charter.pdf, accessed 9 August 2019).

7. Strategies towards ending preventable maternal mortality (EPMM). Geneva: World Health Organization; 2015 (https://apps.who. int/iris/bitstream/handle/10665/153544/9789241508483_eng.pdf?sequence=1, accessed 9 August 2019).

8. Health Statistics Yearbook 2015. Ankara: General Directorate of Health Research, Ministry of Health; 2016.

9. Birth statistics, 2015. Ankara: Turkish Statistical Institute; 2016. (http://www.turkstat.gov.tr/PreHaberBultenleri.do?id=21514, accessed 21 January 2020).

10. Kassebaum NJ, Barber RM, Bhutta ZA, Dandona L, Gething PW, Hay SI et al. Global, regional, and national levels of maternal mortality, 1990-2015: a systematic analysis for the Global Burden of Disease Study 2015. Lancet. 2016;388(10053):1775-812. http:// doi.org/10.1016/So140-6736(16)31470-2

11. 2013 Turkey demographic and health survey. Ankara: Hacettepe University Institute of Population Studies, T.R. Ministry of Development and TÜBİTAK; 2014. Çankaya S, Ak A, Polat Y, Filiz F, Künduro F, Mizrak F et al. Doğum için başvuran gebelerin empatik iletişim beklentilerinin ebeler tarafından karşılanma durumu [Status of meeting the empathic communication expectations of pregnant women applying for delivery by midwives]. Genel Tip Derg. 2014;24(1):7-14.

12. Santas G, Santas F. Trends of caesarean section rates in Turkey. J Obstet Gynaecol. 2018;38(5):658-62. https://doi.org/10.1080/014 43615.2017.1400525

13. Health at a glance 2017: OECD indicators. Paris: OECD Publishing; 2017. https://doi.org/10.1787/19991312

14. Global health observatory data repository. Health service coverage. Data by country. Geneva: World Health Organization; 2019 (http://apps.who.int/gho/data/node.main.REPWOMEN39?lang=en, accessed 6 August 2019). 
15. Sağlık Bakanlığı - Türk Jinekoloji ve Obstetri Derneği sezaryen oranlarını azaltma ortak eylem planı [Ministry of Health Turkish Gynecology and Obstetrics Association joint action plan for reducing cesarean rates]. Ankara: Türk Jinekoloji ve Obstetri Derneği; 2013 (http://www.tjod.org/saglik-bakanligi-tjod-sezaryen-oranlarini-azaltma-ortak-eylem-plani/, accessed 10 March 2019).

16. Sağlık Bakanlığı ve bağlı kuruluşlarının teşkilat ve görevleri hakkında kanun hükmünde kararname ile bazı kanun ve kanun hükmünde kararnamelerde değişiklik yapılmasına dair kanun-No: 6354 [Law amending the decree-law on the organization and duties of the Ministry of Health and its subsidiaries and the amendment of certain laws and decree laws-No: 6354]. Resmi Gazete. 12 July 2012: 28351 (http://www.Resmigazete.Gov.Tr/Eskiler/2012/07/20120712-12.htm, accessed 10 March 2019).

17. Anne Dostu Hastane Programı çerçevesinde. T.C. Sağlik Bakanliği, Kamu Hastaneleri Genel Müdürlüğü, Sağlik Hizmetleri Dairesi Başkanliği [Mother-friendly hospital programme. Ankara: TR Ministry of Health, General Directorate of Public Hospitals, Health Services Department] (https://khgmsaglikhizmetleridb.saglik.gov.tr/TR,50947/quotanne-dostu-hastane-programiquot-cercevesinde-iller-bazinda-yurutulecek-calismalara-yol-gosterecek-nitelikte--hazirlanmis-olan-201827-sayili-genelge-veekleri.html, accessed 30 June 2020).

18. WHO recommendations: intrapartum care for a positive childbirth experience. Geneva: World Health Organization; 2018 (https://apps.who.int/iris/bitstream/handle/10665/260178/9789241550215-eng.pdf?sequence=1, accessed 02 December 2019).

19. Ten steps of the mother-friendly childbirth initiative for mother-friendly hospitals, birth centers, and home birth services [website]. Coalition for Improving Maternity Services; 2015 (http://www.motherfriendly.org/, accessed 10 March 2019).

20. 12 steps to safe and respectful mother baby-family maternity care [Internet]. The International Childbirth Initiative (ICI); 2018 (https://www.whiteribbonalliance.org/wp-content/uploads/2019/11/ICI-full-document_EN_2018-colour_FINAL.pdf, accessed 7 May 2019).

21. Standards for improving quality of maternal and newborn care in health facilities. Geneva: World Health Organization; 2016 (https://apps.who.int/iris/bitstream/handle/10665/249155/9789241511216-eng.pdf?sequence=1, accessed 2 December 2019).

22. Health statistics yearbook 2018. Ankara: Republic of Turkey Ministry of Health General Directorate of Health Information Systems; 2019. (https://dosyasb.saglik.gov.tr/Eklenti/36164,siy2018en2pdf.pdf?o, accessed 22 January 2020).

23. Makvandi S. A look at the normal physiologic childbirth program at the mother-friendly hospitals of the Islamic Republic of Iran. Int J Pregnancy Child Birth. 2018;4(4):181-2. http://doi.org/10.15406/ipcb.2018.04.00106

24. Li YP, Yeh CH, Lin SY, Chen TC, Yang YL, Lee CN, et al. A proposed mother-friendly childbirth model for Taiwanese women, the implementation and satisfaction survey. Taiwan J Obstet Gyne. 2015;54(6):731-6. http://doi.org/10.1016/j.tjog.2015.10.009

25. Batal M, Boulghaurjian C. Breastfeeding initiation and duration in Lebanon: are the hospitals "mother friendly"? J Pediatr Nurs. 2005;20(1):53-9. http://doi.org/10.1016/j.pedn.2004.09.004

26. Anwar AA, Abul-Fadl AM, Noseir M, Mahdy MH. Promoting mother friendly practices as a strategy towards baby friendly hospitals. Egypt J Breastfeed. 2012;4:99-115.

27. Bülbül G. Istanbul'da çalışan kadın hastalıkları ve doğum uzmanlarının doğum şekli ile ilgili görüş ve önerileri [The opinions and recommendations of obstetricians and gynecologists working in Istanbul on mode of delivery]. Istanbul: Marmara University; 2012.

28. Başgöl Ş, Oskay Ü. Ana çocuk sağlığı hizmetlerinin geliştirilmesinde anne dostu hastane modeli [Mother-friendly hospital model in promoting maternal and child health]. Anadolu Hemşirelik ve Sağllk Bilimleri Dergisi. 2014;17(2):125-9.

29. Başkaya Y, Sayıner FD. Sezaryen oranını azaltmaya yönelik kanıta dayalı ebelik uygulamaları [Evidence-based midwifery practices to reduce the cesarean rate]. Arch Health Sci Res. 2018;5(1):113-9. http://doi.org/10.17681/hsp.335472

30. Kahvecioğlu, D, Tatar Aksoy H, Özen G, Yılmaz A, Üstün Y. Kadın hastalıkları ve doğum servisinde doğan, doğum travması nedeniyle takip edilen yenidoğanların tanı ve prognozlarının incelenmesi, anne dostu hastane modelinin doğum travmaları üzerindeki etkisinin değerlendirilmesi. [Evaluation of the impact of mother-friendly hospital model on the diagnosis and prognosis of newborns having birth trauma in our obstetrics and gynecology service]. Ankara Eğt Arş Hast Derg. 2018;51(2):104-9.

31. Bilgiç D, Demirel G, Dağlar G. Gebelerin gebelik dönemine ve doğuma ilişkin mitlerinin belirlenmesi [Determining the myths of pregnant women on the pregnancy period and childbirth]. Zeynep Kamil Tıp Bülteni. 2018;49(1):59-64.

32. Bolsoy N. Türkiye'de ebeliğin güçlendirilmesi: Anne dostu hastane uygulamaları. [Strengthening midwifery: mother-friendly hospital practices]. Celal Bayar University Health Sci Inst J. 2018;5(special issue):39-40.

33. Büken E, Büken NÖ, Büken B. Obstetric and gynecologic malpractice in Turkey: incidence, impact, causes, and prevention. J Clin Forensic Med. 2004;11(5):233-47. http://doi.org/10.1016/j.jcfm.2004.01.005. 